Petrogenesis of Ordovician Magmatism in the Pyrenees (Albera and Canigó Massifs) Determined on the Basis of Zircon Minor and Trace Element Composition Author(s): Pedro Castiñeiras, Marina Navidad, Josep M. Casas, Montserrat Liesa, Jordi Carreras

Source: The Journal of Geology, Vol. 119, No. 5 (September 2011), pp. 521-534

Published by: The University of Chicago Press

Stable URL: http://www.jstor.org/stable/10.1086/660889

Accessed: 31/07/2011 06:06

Your use of the JSTOR archive indicates your acceptance of JSTOR's Terms and Conditions of Use, available at http://www.jstor.org/page/info/about/policies/terms.jsp. JSTOR's Terms and Conditions of Use provides, in part, that unless you have obtained prior permission, you may not download an entire issue of a journal or multiple copies of articles, and you may use content in the JSTOR archive only for your personal, non-commercial use.

Please contact the publisher regarding any further use of this work. Publisher contact information may be obtained at http://www.jstor.org/action/showPublisher?publisherCode=ucpress.

Each copy of any part of a JSTOR transmission must contain the same copyright notice that appears on the screen or printed page of such transmission.

JSTOR is a not-for-profit service that helps scholars, researchers, and students discover, use, and build upon a wide range of content in a trusted digital archive. We use information technology and tools to increase productivity and facilitate new forms of scholarship. For more information about JSTOR, please contact support@jstor.org. 


\title{
Petrogenesis of Ordovician Magmatism in the Pyrenees (Albera and Canigó Massifs) Determined on the Basis of Zircon Minor and Trace Element Composition
}

\author{
Pedro Castiñeiras, ${ }^{1, \star}$ Marina Navidad, ${ }^{1, \dagger}$ Josep M. Casas,,${ }^{2, \neq}$ \\ Montserrat Liesa, ${ }^{3, \S}$ and Jordi Carreras ${ }^{4, \|}$
}

1. Departamento de Petrología y Geoquímica-Instituto de Geología Económica (CSIC), Universidad Complutense de Madrid, José Antonio Novais 2, Madrid 28040, Spain; 2. Departament de Geodinàmica i Geofísica-Institut de recerca GEOMODELS, Universitat de Barcelona, Martí i Franquès s/n, Barcelona 08028, Spain; 3. Departament de Geoquímica, Petrologia i Prospecció Geològica, Universitat de Barcelona, Martí i Franquès s/n, Barcelona 08028, Spain; 4. Departament de Geologia, Universitat Autònoma de Barcelona, Bellaterra (Cerdanyola del Vallès) 08193, Spain

\begin{abstract}
A B S T R A C T
Zircon composition (U, Th, rare earth elements, and Hf) was tested as a tracer of petrogenetic processes in a set of metaigneous rocks from two pre-Ordovician massifs in the Pyrenees, Canigó and Albera. Two groups were differentiated after analyzing a number of elements in zircon: (1) Casemí gneiss and Marialles amphibolite and (2) subvolcanic metaporphyries and Cadí and Sureda orthogneisses. Casemí gneiss and Marialles amphibolite from the Canigó massif have high Th, Th/U, and Ce/Sm and low $\mathrm{Yb} / \mathrm{Gd}$ and $\mathrm{U} / \mathrm{Ce}$ that define linear trends in most of the plots used. The anomalous trend of the data in the Th/U-versus-Hf plot suggests mantle involvement in the origin of these rocks and the participation of fractional crystallization during their evolution. Zircon of the metaporphyries and the Cadí and Sureda orthogneisses exhibit similar characteristics despite a difference in age. Zircon has low Th, Th/U, Ce/ $\mathrm{Sm}$, and $\mathrm{Eu} / \mathrm{Eu}^{*}$ and high $\mathrm{Yb} / \mathrm{Gd}$ and $\mathrm{U} / \mathrm{Ce}$, suggesting that this mineral grew in a melt formed by anatexis of a continental crust, with stable plagioclase. These petrogenetic data are consistent with the previously studied wholerock geochemistry and Sr-Nd isotopes and confirm the use of zircon as a marker of petrogenetic processes in preference to a lithological tracer.
\end{abstract}

Online enhancements: appendix table, Excel file.

\section{Introduction}

In recent years, a large number of compositional studies of zircon have been undertaken to define reliable chemical discriminants and link zircon composition with its host rock (e.g., Murali et al. 1983; Heaman et al. 1990; Hinton and Upton 1991; Ireland and Wlotzka 1992; Barbey et al. 1995; Belousova et al. 1998; Hoskin 1998). Such discriminants could be especially useful in detrital zircon 2011.

Manuscript received March 29, 2010; accepted April 27,

* Author for correspondence; e-mail: castigar@geo.ucm.es.

† E-mail: navidad@geo.ucm.es.

‡ E-mail: casas@ub.edu.

$\S$ E-mail: mliesa@ub.edu.

I| E-mail: jordi.carreras@uab.cat. populations and in xenocrystic zircon grains from igneous rocks, where information about the source rocks is absent (Heaman et al. 1990). By contrast, the use of zircon as a lithological tracer has been challenged because this mineral generally exhibits a similar composition in a wide range of crustal rock types (Hoskin and Ireland 2000). Nevertheless, zircon has been successfully used to identify petrogenetic processes in metamorphic and magmatic rocks.

In metamorphic rocks, considerable effort has been devoted to linking ages obtained from different zircon zones with specific portions of the pressure-temperature path on the basis of its compositional features (Hoskin and Black 2000; Rubatto

[The Journal of Geology, 2011, volume 119, p. 521-534] (c) 2011 by The University of Chicago. All rights reserved. 0022-1376/2011/11905-0006\$15.00. DOI: 10.1086/660889 
2002; Hoskin and Schaltegger 2003; Whitehouse and Platt 2003; Hokada and Harley 2004; Kelly and Harley 2005; Puga et al. 2005; Whitehouse and Kamber 2005; McClelland et al. 2006; Chen et al. 2010). Zircon is likely to undergo substantial chemical changes in the presence of selected mineral phases, which can be linked to unequivocal metamorphic conditions. For example, concurrent growth of garnet and zircon results in a strong depletion of heavy rare earth elements (REEs) in zircon because of the relative preference of garnet for incorporating them (Rubatto 2002; Hokada and Harley 2004; Puga et al. 2005). Plagioclase, if present, affects the europium content of zircon, inducing a pronounced negative anomaly (Hoskin and Schaltegger 2003). The absence of this anomaly can be used to infer that plagioclase is not stable, which is typical of rocks metamorphosed under eclogitic conditions (Rubatto 2002; Puga et al. 2005; McClelland et al. 2006; Chen et al. 2010).

In magmatic rocks, zircon composition has been used to constrain the age of a magmatic event when the geochronological data show a wide age range (Castiñeiras et al. 2010), which is not uncommon in crustal and arc melts (Compston 2000; Coleman et al. 2004; Miller et al. 2007; Kelly et al. 2008). Moreover, the chemical composition of zircon can be used to identify a variety of petrogenetic processes, such as fractionation and recharging of magma chambers-Claiborne et al. (2006, 2010a) assessed the behavior of hafnium during fractional crystallization, combining the preference of this element for concentrating in zircon with temperature data obtained by means of Ti-in-zircon thermometry (Watson and Harrison 2005), and found that titanium and hafnium were inversely correlated, giving rise to an increase in hafnium as temperature decreases. These investigators also interpreted the opposite correlation as resulting from a recharge in the magma chamber and entrainment of zircon in a less fractionated melt. More recently, du Bray et al. (2011) suggested that the reliability of hafnium as a fractionation index could be assessed by comparing its concentration with the europium anomaly. Claiborne et al. $(2010 b)$ proposed additional differentiation indexes for felsic magmatic systems (Th/U and $\mathrm{Yb} / \mathrm{Gd}$ ratios). In a like manner, Barth and Wooden (2010) used the composition and compositional trends of zircon to elucidate igneous processes during magmatic evolution and to identify general compositional characteristics of melts not only in magmatic zircon but also in inherited zircon. These authors concluded that the temperature-dependent fractionation indexes (i.e., Hf, $\mathrm{Yb}$ / $\mathrm{Gd}$, and $\mathrm{Th} / \mathrm{U}$ ) are superimposed on persistent pa- rental melt compositional differences, validating their use as petrogenetic tracers. Moreover, the $\mathrm{Zr}$ / Hf ratio in zircon from S- and I-type granites and lower crust rocks was used by Pérez Soba et al. (2007) to identify crustal sources. Grimes et al. (2007) used the chemical composition of zircon to discriminate between zircon grown in a reservoir such as modern mid-ocean ridge basalts and zircon grown in continental crust magmas. Finally, Gagnevin et al. (2010), using the texture and composition of zircon, identified magma hybridization processes in a complex igneous system and provided insights into the nature of the end members involved in the mixing process.

The aim of this work is to describe and interpret the chemical composition (U, Th, REEs, and Hf) of zircon in seven igneous samples metamorphosed under high-temperature and low-pressure conditions from the Canigó and Albera massifs in the Pyrenees (figs. 1, 2). Our interpretation of zircon chemistry in the studied samples is based on the compositional trends described by other authors in evolving magmatic systems. Comparison of the petrogenetic information obtained from zircon chemistry with the available whole-rock geochemistry and neodymium isotope data (Navidad et al. 2010; Liesa et al. 2011) suggests that zircon composition can be used as a tracer of petrogenetic magmatic processes. Furthermore, it may be used to characterize different melt compositions, even in metamorphosed igneous rocks.

\section{Geological Setting}

The Albera and Canigó massifs are located in the eastern part of the Pyrenees, where pre-Alpine basement rocks are widely exposed (fig. 1). Both massifs exhibit a domelike structure cut by Neogene normal faults, which accounts for the outcrop of the lowermost rocks in the central part of the massifs. Three main lithological units can be distinguished: (1) a pre-Upper Ordovician metasedimentary sequence, (2) large orthogneissic bodies, and (3) Variscan plutonic rocks, mainly granitoids (figs. 1, 2).

1. The pre-Upper Ordovician metasedimentary sequence is composed of alternating layers of metagreywackes and metapelites with abundant and discontinuous layers of metabasites, calc-silicate rocks, quartzites, and marbles in its lower part. Its upper part is mainly formed by alternating layers of metapelites and metapsammites. The age of the sequence is uncertain because of the absence of fossil content, although a Cambro-Ordovician (pre-Caradocian) age has classically been inferred (Fontboté 1949; Cavet 1959). Mid-Late Cambrian (Laumonier 


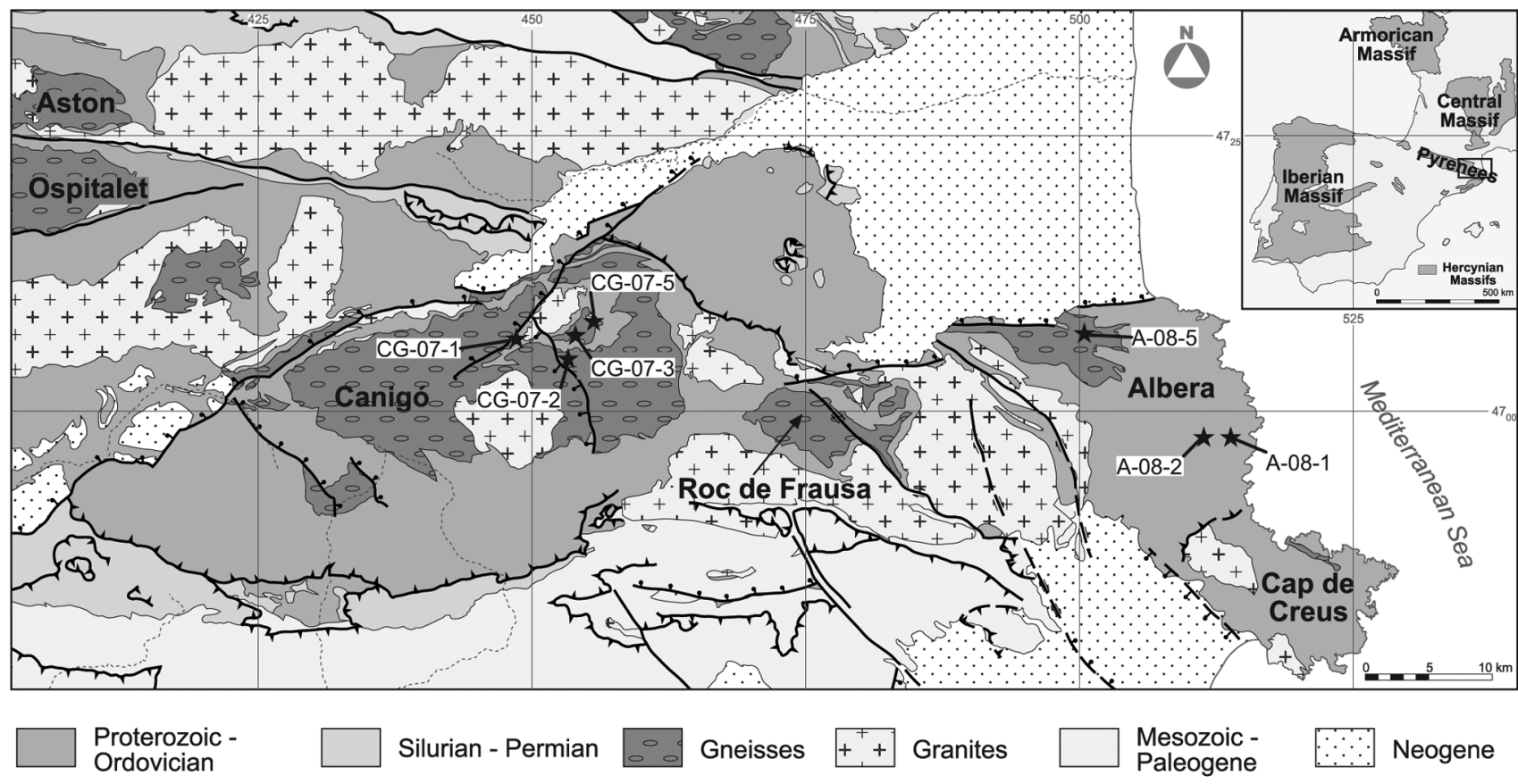

Figure 1. Geological sketch of the Variscan basement and cover sequences of the eastern Pyrenees, with locations of the study areas. A color version of this figure is available in the online edition of the Journal of Geology.

1988; Perejón et al. 1994) or Late Cambrian-Early Ordovician (Guitard et al. 1998) ages have been proposed for its upper part, whereas radiometric dating of interlayered metatuffs has yielded a Late Neoproterozoic-Early Cambrian age $(580-540 \mathrm{Ma})$ for its lower part (Cocherie et al. 2005; Castiñeiras et al. 2008).

2. Orthogneissic bodies, ranging in thickness from $500 \mathrm{~m}$ in the Albera massif to $3000 \mathrm{~m}$ in the Canigó massif (the Sureda and Canigó gneisses, respectively; Guitard 1970) constitute the main interlayered units in the pre-Upper Ordovician metasedimentary sequence (fig. 2). The orthogneisses are derived from K-feldspar phenocryst-rich aluminous granitic bodies. Some acidic subvolcanic dikes of rhyolitic metaporphyries crosscutting the series can also be identified in the Albera massif. Geochronological data strongly suggest that a welldefined Early-Mid Ordovician magmatic event brought about the intrusion of the two granitic bodies (Canigó gneiss: $477 \pm 4$ to $467 \pm 7 \mathrm{Ma}$ [Cocherie et al. 2005]; Sureda gneiss: $470 \pm 3 \mathrm{Ma}$ [Liesa et al. 2011]) and the acid subvolcanic porphyritic dikes (472 \pm 3 and $465 \pm 4 \mathrm{Ma}$; Liesa et al. 2011). These ages fit in well, within error, with those obtained for the protoliths of other Pyrenean orthogneisses: Roc de Frausa gneiss $(476 \pm 5 \mathrm{Ma}$; Castiñeiras et al. 2008) and Aston and Hospitalet gneisses $(472 \pm 2$ and $470 \pm 6 \mathrm{Ma}$, respectively; Denele et al. 2009). Moreover, the Canigó massif exposes a succession of micaschists up to $1500 \mathrm{~m}$ thick containing several metaigneous interlayered bodies in its central part and under the Canigó gneiss (fig. 2). The Casemí gneiss (Guitard 1970) constitutes the most significant metaigneous intercalation. It is a tabular body up to $1000 \mathrm{~m}$ thick and is mainly made up of fine-grained biotitic and amphibolic granitic gneiss. U-Pb ion probe zircon data indicate a Late Ordovician age for the protolith of this orthogneiss $(451 \pm 5$ and $445 \pm 5 \mathrm{Ma}$; Casas et al. 2010). The Marialles amphibolite, which comprises meter-scale-thick bodies interlayered in the micaschists, also yields a Late Ordovician age for the formation of its protolith $(453 \pm 4 \mathrm{Ma}$, SHRIMP U-Pb in zircon; Casas et al. 2010). The structurally lowest unit recognized in the Canigó massif is the Cadí gneiss (Guitard 1970), an aluminous metagranite that is similar to the Canigó gneiss, but younger $(456 \pm 5 \mathrm{Ma}$, SHRIMP U-Pb in zircon; Casas et al. 2010).

3 . Variscan intrusives are represented by syn- to late-orogenic (Moscovian-Kasimovian; Romer and Soler 1995) granitoids, which intruded mainly into the upper levels of the succession, resulting in local contact metamorphism (Autran et al. 1970; Vilà 2003). 
(a) Canigó Massif

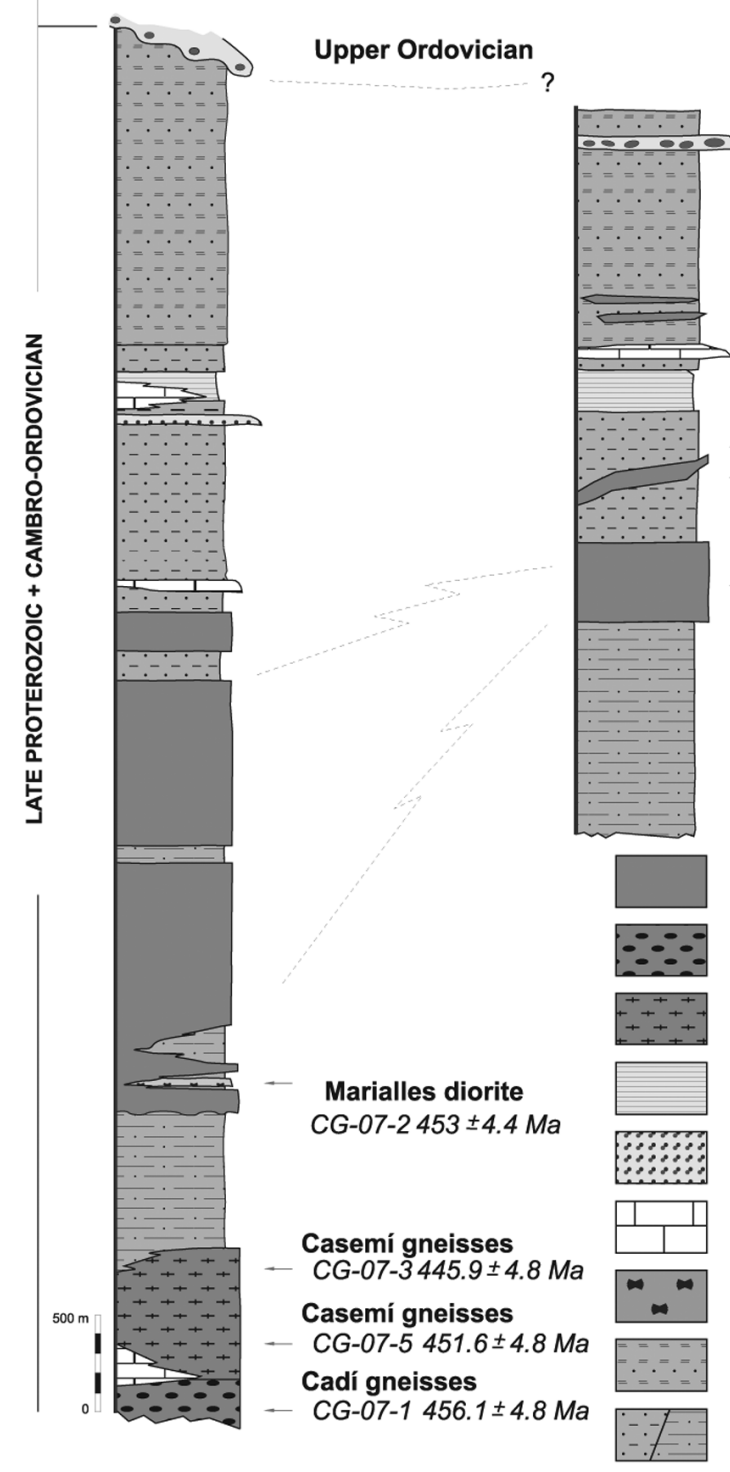

(b) Albera Massif

Rhyolitic metaporphyries

AO801 $465 \pm 3 \mathrm{Ma}$ AO802 $472 \pm 3 \mathrm{Ma}$

Sureda gneisses

AO805 $470 \pm 3 \mathrm{Ma}$

Canigó and Sureda gneisses

Cadí gneisses

Casemí gneisses

Black phyllites

Conglomerates

Marbles

and dolomites

Metabasites

Siltstones amb Q-Ms rhytmites

Metapelites and metagrawackes

Figure 2. Synoptic stratigraphic columns of the pre-Upper Ordovician rocks of the Canigó massif $(a)$ and Albera massif (b) showing sample locations. Geochronological data are from Casas et al. (2010) and Liesa et al. (2011). A color version of this figure is available in the online edition of the Journal of Geology.

\section{Analytical Methods}

Zircon separation was performed at the Universidad Complutense (Madrid) by standard techniques, including crushing, pulverizing, and sieving, as well as a combination of gravimetric (Wilfley table and methylene iodide) and magnetic (Frantz isodynamic separator) techniques.

The zircon grains were handpicked under a binocular microscope at the Stanford-USGS MicroAnalytical Center (SUMAC), selecting the most transparent and idiomorphic zircon grains with the highest length-to-width ratios to avoid inherited and metamorphic zircons and inclusions. Samples from the Canigó and Albera massifs were mounted separately on glass slides with a double-sided adhesive in $1 \times 6-\mathrm{mm}$ parallel rows and set in epoxy resin. Thereafter, the mounts were ground down to expose their central portions by using 1500 -grit wet sandpaper and polished with 6- and 1- $\mu \mathrm{m}$ diamond abrasives on a lap wheel. Before analysis, the internal structure, inclusions, fractures, and physical defects were identified with transmitted and reflected light on a petrographic microscope and with cathodoluminescence (CL) on a JEOL 5600LV scan- 
ning electron microscope. After analysis, secondary electron images were obtained to locate the exact position of the spots.

REE and hafnium analyses of zircon were performed using a SHRIMP-RG (reverse geometry), operated by the SUMAC facility, concurrently with $\mathrm{U}-\mathrm{Th}-\mathrm{Pb}$ isotopes (published elsewhere; Casas et al. 2010; Liesa et al. 2011) during two analytical sessions in May 2008.

Secondary ions were generated from the target spot with an $\mathrm{O}^{2-}$ primary ion beam varying from 4 to $6 \mathrm{nA}$. The primary ion beam produced a spot with a diameter of $\sim 25 \mu$ and a depth of $1-2 \mu$ for 12-13 min. Data for each spot were collected using five-cycle runs through the mass stations, including U-Pb isotopes (see Casas et al. 2010; Liesa et al. 2011). Data reduction was done using an inhouse Excel spreadsheet, and Isoplot software (Ludwig 2003) was used to create the graphs.

The concentrations of $\mathrm{U}, \mathrm{Th}, \mathrm{Hf}$, and REEs were calibrated using an in-house zircon standard (Madagascar green zircon) and are reproducible at $2 \%-$ $4 \%(1 \sigma)$, except for La $(15 \%)$ because of the typically low concentration of La (see Barth and Wooden 2010). Praseodymium was calculated from neighboring elements because $\mathrm{CeH}$ cannot be resolved from the praseodymium peak and contributes significantly to the counts at $\operatorname{Pr}^{141}$ given the low amount of praseodymium and the relatively high cerium concentration.

\section{Samples Investigated}

The selected samples from the Canigó massif crop out at the lowest structural level. The Cadí orthogneiss (sample CG-07-1; figs. 1, 2) is intercalated in the pre-Upper Ordovician series with higher metamorphism (sillimanite-K-feldspar). It exhibits a porphyroclastic texture with a pervasive foliation. The mineral paragenesis is made up of quartz, biotite, plagioclase, and K-feldspar. The Casemí orthogneiss is a deformed tabular body that exhibits a domelike structure. To the north of the Canigó peak (fig. 1), the base of the body consists of felsic and biotitic orthogneisses that grade to amphibolic orthogneiss to the south. The metasedimentary host rocks exhibit different metamorphic conditions at their lower and upper contacts (sillimanite$\mathrm{K}$-feldspar and andalusite zones, respectively). The biotitic Casemí orthogneiss (sample CG-07-3) shows metamorphic paragenesis constituted by quartz, microcline, biotite, and albite-rich plagioclase, with muscovite, epidote, and titanite as retrograde minerals. The amphibolic Casemí orthogneiss (sample CG-07-5) is mainly composed of
Fe-hornblende and plagioclase (An35-40), whereas biotite and K-feldspar are present in the biotitic orthogneiss. Zircon, apatite, and allanite are the main accessory minerals. Both gneiss types are recrystallized, and their texture varies between granoblastic and granolepidoblastic depending on the abundance of biotite. The Marialles amphibolite (sample CG-07-2) crops out as a thin, discontinuous layer interbedded in the metasediments along the southern contact of the Casemí gneiss. The amphibolite shows a metamorphic paragenesis made up of plagioclase (oligoclase), Fe-hornblende, and biotite, with titanite as accessory mineral. The texture is predominantly nematogranoblastic, with some lepidoblastic domains randomly distributed. Whole-rock geochemistry indicates that the protolith had a dioritic composition.

The samples selected from the Albera massif intrude the middle sector of the pre-Upper Ordovician metasediments (figs. 1, 2). Samples A-08-1 and A-08-2 are fine-grained rocks with discontinuous green- to gray-colored thin foliated layers. They are mainly made up of quartz and minor feldspar porphyroclasts $(1-5 \mathrm{~mm})$ that are conspicuous in a fine-grained groundmass $(0.02-0.05 \mathrm{~mm})$ composed of quartz, altered feldspar, and phyllosilicates (light brown biotite, muscovite, and scarce chlorite). The micas define an anastomosing foliation that wraps the porphyroclasts. Quartz is rounded with deep embayments characteristic of magmatic corrosion. Field relations together with the compositional and textural features of these rocks allow us to interpret them as former hypabissal or subvolcanic rocks, probably granitic porphyries.

Sample A-08-5 (figs. 1, 2) is an augen orthogneiss locally known as "Sureda gneiss." It has a granitic composition and is constituted by quartz, microcline, plagioclase, biotite, and small amounts of muscovite and opaque ore. Biotite and muscovite define a coarse, discontinuous foliation separating quartz-feldspar microlitons 2-3 $\mathrm{mm}$ thick. Quartz displays a relatively uniform grain size of $0.4 \mathrm{~mm}$. Microcline and plagioclase constitute porphyroclasts that range from 1 to $4 \mathrm{~cm}$. Microcline is perthitic and exhibits tartan twinning due to deformation.

Geochemically (table A1, available in the online edition or from the Journal of Geology office), all the samples are felsic, ranging from 69 to $75 \mathrm{wt} \%$ in $\mathrm{SiO}_{2}$ content, except the Marialles amphibolite $\left(\mathrm{SiO}_{2}=50 \mathrm{wt} \%\right)$. Zirconium content in most of the samples varies between 170 and $340 \mathrm{ppm}$, with the lowest values for the amphibolite (CG-07-2; 140 $\mathrm{ppm}$ ) and for one of the metaporphyries (A-08-2; 60 ppm). $\mathrm{Zr} / \mathrm{Hf}$ ratios are close to chondritic $(\sim 35-40$; 


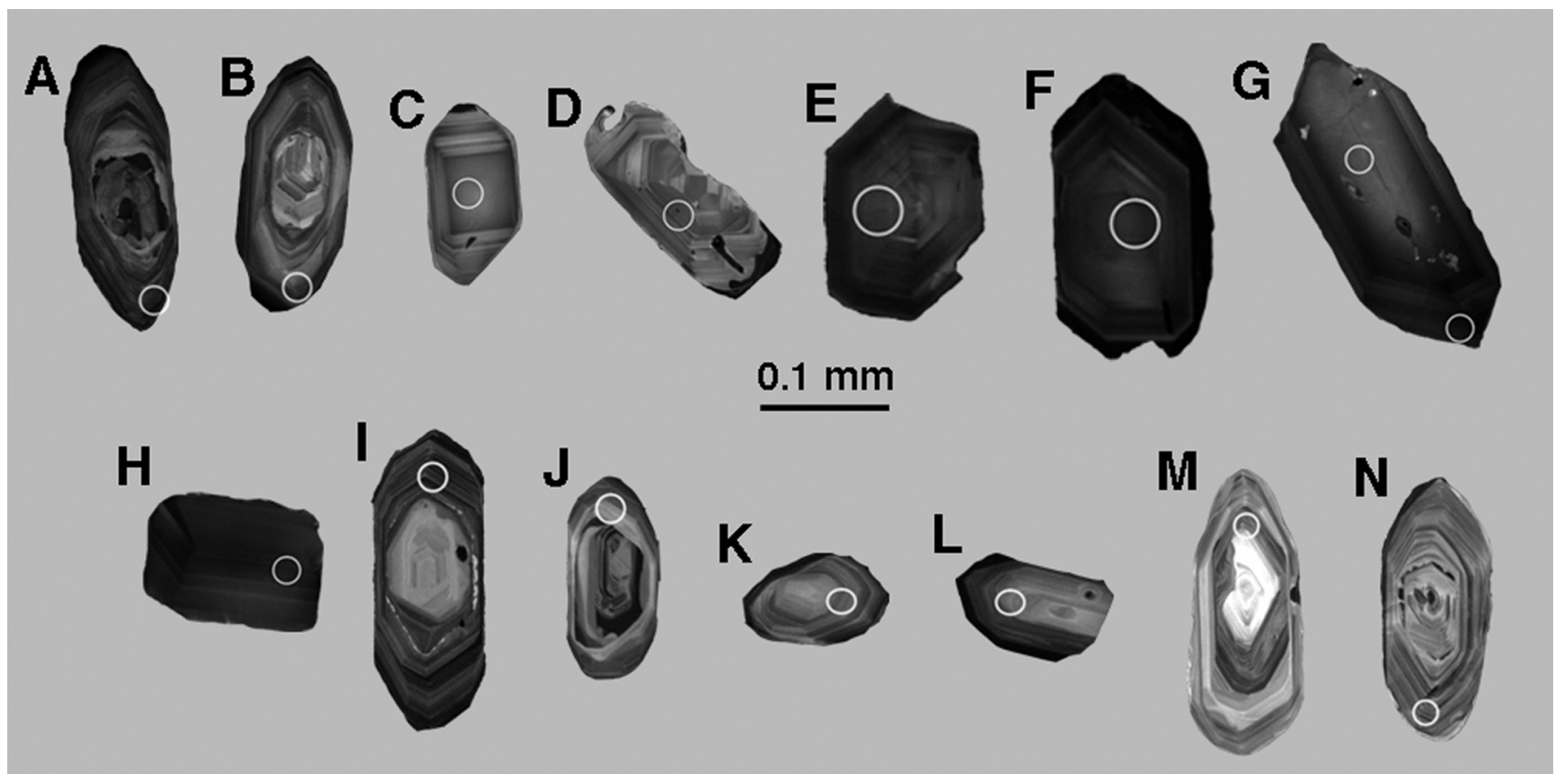

Figure 3. Cathodoluminescence images of selected zircons from the Canigó and Albera samples. $A, B$, Sample CG07-1; $C$, $D$, sample CG-07-3; E, F, sample CG-07-5; G, H, sample CG-07-2; $I$, I, sample A-08-1; $K$, $L$, sample A-08-2; $M, N$, sample A-08-5. The circles represent the location of the ion microprobe analyses.

see Claiborne et al. 2006), except in sample A-08$2(\mathrm{Zr} / \mathrm{Hf}=20)$. The alkaline index $(\mathrm{M}$; see Hanchar and Watson 2003) ranges between 0.9 and 1.3, with the highest value for the amphibolite CG-07-2 $(M=2.9)$. The zircon saturation temperatures $\left(T_{\text {sat }}\right)$ calculated using the methods of Hanchar and Watson (2003) vary between $715^{\circ} \mathrm{C}$ and $875^{\circ} \mathrm{C}$ for all the samples with the exception of sample CG-072 , which has the lowest saturation temperature $\left(T_{\text {sat }}=680^{\circ} \mathrm{C}\right)$.

Neodymium isotope analyses are available for the Canigó massif samples only (Navidad et al. 2010). Sample CG-07-1 is enriched in $\varepsilon \mathrm{Nd}_{t}$ values $\left(\varepsilon \mathrm{Nd}_{t}=-4.2\right)$, suggesting a crustal origin. Samples CG-07-2, CG-07-3, and CG-07-5 are less enriched $\left(\varepsilon \mathrm{Nd}_{t}=-0.6,-1.7\right.$, and -1.2 , respectively $)$ and are interpreted as mantle-derived melts with variable crustal contamination (Navidad et al. 2010). Notwithstanding the isotopic evidence of different magma sources for these samples, all petrographic manifestations of magma mixing were obliterated by metamorphic recrystallization. As for the Albera massif samples, the absence of coeval mafic rocks suggests that they are derived from crustal melts (Liesa et al. 2011).

\section{Zircon Petrography}

Canigó Massif. Zircon prisms from sample CG07-1 have width-to-length ratios between $1: 2$ and $1: 3$ and well-developed composite pyramidal faces. They are colorless to pale yellow and are virtually free of inclusions. Under CL, they exhibit clear core-rim structures, with abundant inherited cores rimmed by magmatic oscillatory zones (fig. $3 A, 3 B)$.

Zircon grains from sample CG-07-3 are broken colorless prisms with simple pyramids, irregular faces, and common inclusions. Under CL, they are luminescent, with some grains displaying broad homogeneous or sector-zoned central areas surrounded by finely zoned oscillatory bands; otherwise, the whole grain has an oscillatory zoning (fig. $3 C, 3 D$ ). In sample CG-07-5, zircons are small, stubby, colorless to deep-brown grains with pitted faces and some inclusions. They are moderately luminescent, with oscillatory zoning (fig. $3 E, 3 F$ ).

Zircon grains from sample CG-07-2 are big, broken, colorless to brownish prisms with tetragonal pyramids and irregular or pitted faces. They contain abundant inclusions of nonluminescent minerals, probably major minerals. Zircon textures are uni- 
form, with poor luminescence and homogeneous central areas surrounded by hazy oscillatory zones (fig. $3 G, 3 H$ ). Inherited zircon was not recognized.

Albera Massif. Zircon crystals from sample A-081 (rhyolitic metaporphyry) are colorless, pale yellow, or light purple and contain few inclusions. Mineral habit is variable, commonly plain prisms with differently shaped pyramid terminations and width-to-length ratios between $1: 3$ and $1: 5$. In other cases, the prisms are composite, resulting in stubbier zircons (aspect ratios of $1: 1$ or $1: 2$ ). Broken and moderately rounded grains are common regardless of their habit. Under CL, they exhibit clear core-rim structures with abundant inherited cores mantled by magmatic oscillatory zones (fig. $3 I, 3 J)$.

Unlike sample A-08-1, the zircon yield from another rhyolitic metaporphyry (sample A-08-2) was poor, with less than a hundred grains extracted from $\sim 20 \mathrm{~kg}$ of rock. Zircons are mainly brownish and are practically free of inclusions. The most frequent habits are simple dipyramidal prisms and equant grains, owing to the presence of composite faces. CL reveals a luminescent oscillatory zoning in the majority of grains, commonly surrounded by poorly luminescent rims (fig. $3 K, 3 L$ ). The sharp limit between areas with different luminescence indicates that there was no zircon resorption before the rim growth, suggesting a magmatic rather than a metamorphic origin for these grains. Xenocryst cores are rare.

Sample A-08-5 provided the best zircon yield. Zircon grains are either colorless or colored in different yellow tones, with few inclusions. The most common habit is simple dipyramidal prisms with aspect ratios between $1: 3$ and $1: 5$, but more complex habits or rounded grains can also be found. Under CL, zircons display broad oscillatory zones, typical of magmatic environments (fig. $3 M, 3 N$ ) and common inherited cores.

\section{Zircon U, Th, Hf, and REE Composition}

A total of 103 zircon secondary-ion mass spectrometry analyses were performed (see the supplemental Excel file available in the online edition). Fifty-four zircon grains from the Canigó samples and 49 zircon grains from the Albera samples were analyzed using CL images to target oscillatory or homogeneous zones regarded as magmatic. Analysis 13 from the Cadí orthogneiss (sample CG-07-1) was performed in an inherited grain $(703 \pm 8 \mathrm{Ma}$; Casas et al. 2010) and will not be considered. Figures 4 6 show an assortment of elemental ratios and con-
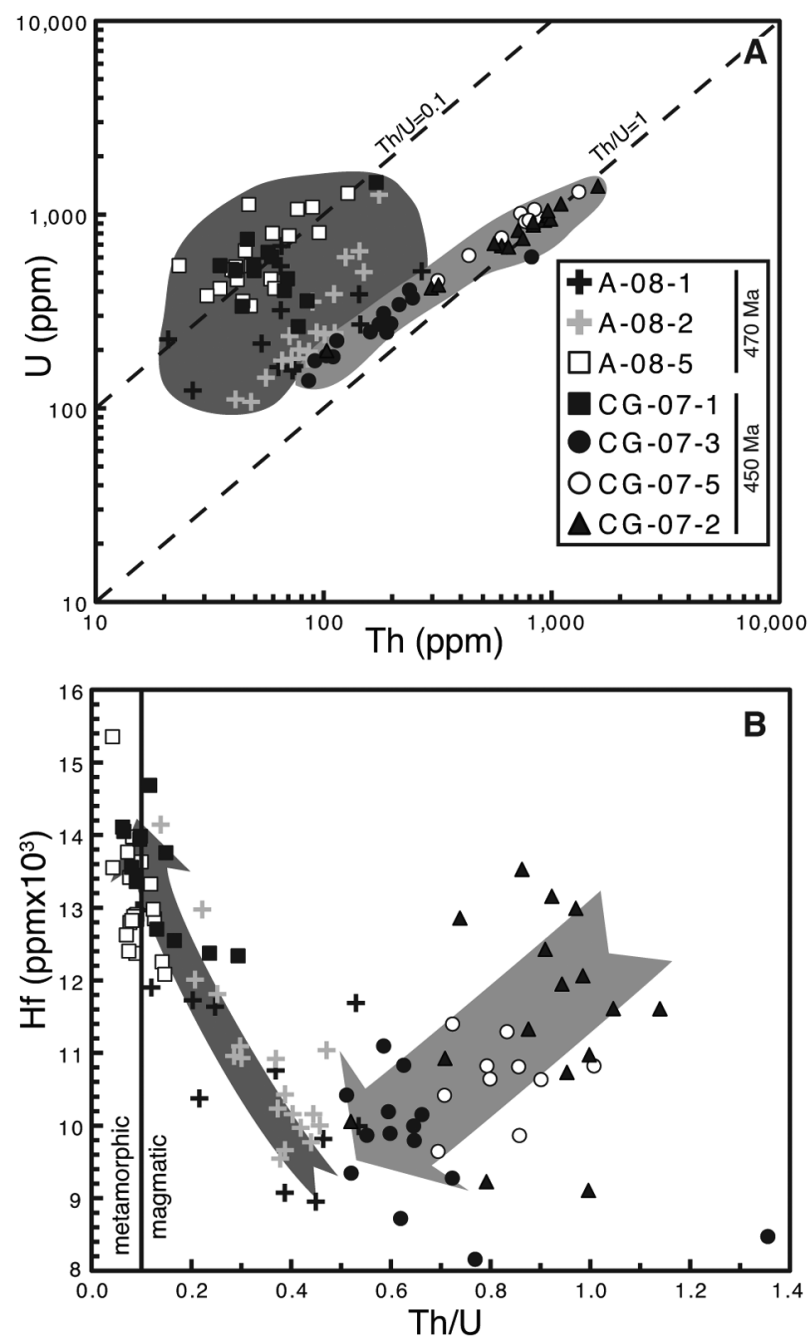

Figure 4. Diagrams showing the main compositional features of the zircons from the Canigó and Albera samples. $A, \mathrm{U}$ versus $\mathrm{Th} ; B$, Hf versus Th/U. See text for details. A color version of this figure is available in the online edition of the Journal of Geology.

centrations and the amount of chondrite-normalized REEs for zircons in each sample.

$\boldsymbol{U}, \boldsymbol{T h}$, and $\boldsymbol{H} \boldsymbol{f}$. Uranium concentrations range from 100 to $1450 \mathrm{ppm}$ (see the supplemental Excel file), with the lowest values in samples CG-07-3 (mean of $260 \mathrm{ppm}$ ) and in A-08-1 and A-08-2 (mean of $320 \mathrm{ppm}$ ). Samples CG-07-1 and A-08-5 have intermediate values (mean of 500 and $650 \mathrm{ppm}$, respectively). The highest values are found in samples CG-07-5 (871 ppm) and CG-07-2 (809 ppm).

Thorium concentrations are scattered between 20 and $1600 \mathrm{ppm}$, with the lowest values corresponding to samples CG-07-1 and A-08-5 (mean of 55 ppm). Samples A-08-1 and A-08-2 from Albera 


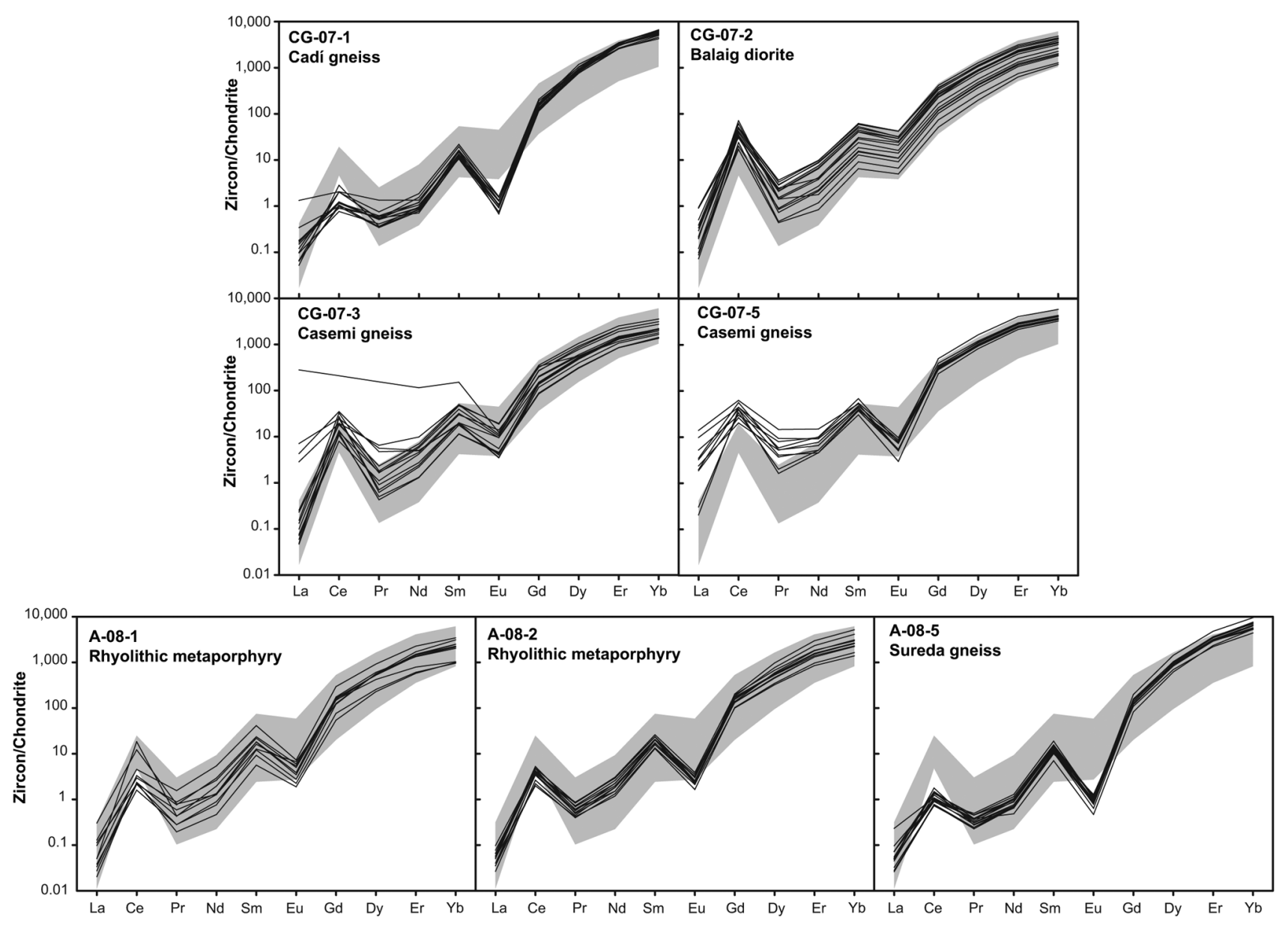

Figure 5. Chondrite-normalized rare earth element (REE) patterns for the Canigó and Albera samples. Chondrite REE contents are from Anders and Grevesse (1989), modified by Korotev (1996). Data from zircon standard R33 (Black et al. 2004) are plotted for comparison (gray fields).

and sample CG-07-3 from Canigó have an intermediate thorium content (mean of 90 and $160 \mathrm{ppm}$, respectively). The highest values correspond to samples CG-07-2 and CG-07-5, which have a mean of $750 \mathrm{ppm}$.

In the Th-versus-U graph (fig. $4 A$ ), there are significant compositional differences between zircons from the mantle-derived rocks (samples CG-07-2, CG-07-3, and CG-07-5; light gray field in fig. 4A) and those derived from crustal melts (samples CG07-1, A-08-1, A-08-2, and A-08-5; dark gray field in fig. 4A). For the mantle-derived rocks, $U$ and Th have a good positive correlation. This linear trend is better defined by the Casemí samples (CG-07-3 and CG-07-5), whereas sample CG-07-2 is closer to a $T h / U$ ratio of 1 . As for the orthogneiss samples, CG-07-1 and A-08-5 exhibit Th/U values of 0.1 , but the data are more scattered. Sample A-08-2 has a relatively good correlation between $\mathrm{Th}$ and $\mathrm{U}$ in contrast to the other metaporphyry (sample A-081), whose Th and $U$ concentrations are fairly scattered, with $\mathrm{Th} / \mathrm{U}$ ratios between 1 and 0.1 .

Concentrations of hafnium range from 8000 to $15,000 \mathrm{ppm}$ (see the supplemental Excel file). The lowest values are found in samples CG-07-3 and CG-07-5 (mean values of 9700 and 10,600 ppm, respectively) and in the metaporphyry samples (A08-1 and A-08-2, with mean values close to 11,000 $\mathrm{ppm}$ ). Zircon from sample CG-07-2 has values ranging between 9100 and 13,500 ppm, whereas zircon from samples CG-07-1 and A-08-5 has the highest Hf contents, ranging from 12,000 to $15,500 \mathrm{ppm}$.

In the Th/U-versus-Hf diagram (fig. $4 B$ ), two contrasting tendencies can be distinguished depending on the origin of the rocks. In the crustal-derived rocks, data from sample A-08-1 are the most scat- 

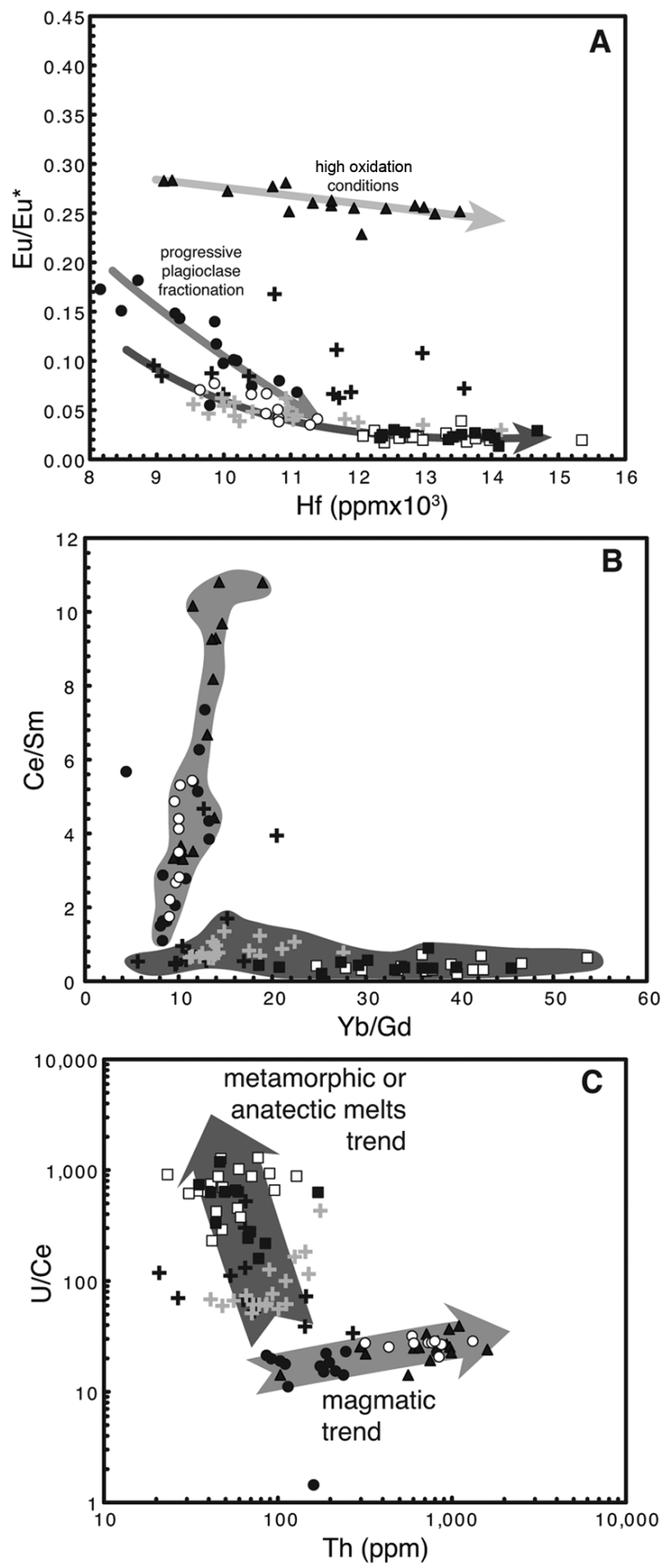

Figure 6. Compositional diagrams providing petrogenetic information from the analyzed zircon. $A, \mathrm{Eu} / \mathrm{Eu}^{*}$ versus Hf (influence of plagioclase fractionation in the zircon composition); $B, \mathrm{Ce} / \mathrm{Sm}$ versus $\mathrm{Yb} / \mathrm{Gd}$ (proxy of the oxidation conditions with fractional crystallization); $C, \mathrm{U} / \mathrm{Ce}$ versus Th (differentiates magmatic from metamorphic or anatectic environments). Symbols are as in figure 4. A color version of this figure is available in the online edition of the Journal of Geology. tered, whereas samples A-08-5 and CG-07-1 are more closely grouped and have similar values. Data from sample A-08-2 follow a trend that includes the other samples. This trend shows a good correlation between the $\mathrm{Th} / \mathrm{U}$ ratio and the Hf concentration in zircon, with the result that the samples with the highest $\mathrm{Th} / \mathrm{U}$ ratio have the lowest Hf contents, whereas the samples with a low $\mathrm{Th} /$ $\mathrm{U}$ ratio have a high $\mathrm{Hf}$ concentration (dark gray field in fig. $4 B$ ). There is substantial scatter in the data from the samples with mantle affinity (CG-07-2, CG-07-3, and CG-07-5). However, a tendency from high to low $\mathrm{Th} / \mathrm{U}$ and $\mathrm{Hf}$ contents can be assumed (light gray field in fig. 4B).

REEs. Total concentrations of these elements range from 400 to $3000 \mathrm{ppm}$ and are considered to be magmatic in most zircons. Relative enrichment in light REEs can be attributed to either metamictization (Belousova et al. 2002) or the presence of small inclusions of a light REE-rich accessory mineral (monazite or allanite; Whitehouse 2003).

The typical chondrite-normalized REE pattern of a magmatic zircon is shown by zircon standard R33 (gray fields in fig. 5; Black et al. 2004). This pattern depicts a moderate fractionation from lanthanum (La) to ytterbium $(\mathrm{Yb})$, with two prominent anomalies in cerium (positive) and europium (negative). Figure 5 shows that the zircons have REE concentrations similar to those of standard R33, except for some cases where the cerium and europium anomalies differ. Furthermore, there are differences in the fractionation of the heavy REEs.

However, to obtain the best petrogenetic information from zircon we used a variety of elemental concentrations and ratios, such as those presented in figure 6. Europium anomaly $\left(\mathrm{Eu} / \mathrm{Eu}^{*}\right)$ is calculated as the geometric mean of the neighboring REEs (Sm and Gd; Taylor and McLennan 1985). Even though oxygen fugacity regulates the europium oxidation state, europium concentration in zircon is mainly influenced by the presence of plagioclase (Hoskin and Schaltegger 2003).

In the $\mathrm{Eu} / \mathrm{Eu}^{*}$-versus-Hf plot (fig. $6 A$ ), the rocks derived from crustal melts define a trend where the europium anomaly is more pronounced as the $\mathrm{Hf}$ content increases. Again, data from sample A-08-1 are the most scattered, whereas samples A-08-5 and CG-07-1 display a prominent europium anomaly. The mantle-derived samples (CG-07-2, CG-07-3, and CG-07-5) reveal differences. On the one hand, samples CG-07-3 and CG-07-5 (Casemí orthogneisses) present intermediate europium anomalies that become deeper as the Hf content increases, suggesting that Hf can be regarded as a good frac- 
tionation index even in rocks with mantle affinity (du Bray et al. 2011). On the other hand, the europium anomaly is subdued in sample CG-07-2, resulting in a subhorizontal trend (fig. 6A).

Cerium anomaly is preferably evaluated using the $\mathrm{Ce} / \mathrm{Sm}$ ratio instead of $\mathrm{Ce} / \mathrm{Ce}^{*}$, given that the latter is fairly sensitive to small variations in $\mathrm{La}$, Pr, and Nd concentrations (Wooden et al. 2006). In figure $6 B, \mathrm{Ce} / \mathrm{Sm}$ is plotted against $\mathrm{Yb} / \mathrm{Gd}$, and a pronounced split in the data can be observed. The samples derived from crustal melts (A-08-1, A-082, A-08-5, and CG-07-1) have Ce/Sm values that are generally below 1.0 and variable $\mathrm{Yb} / \mathrm{Gd}$ ratios, whereas the mantle-derived rocks (CG-07-2, CG07-3, and CG-07-5) show the opposite behavior: $\mathrm{Yb} /$ Gd values are between 10 and 20 and Ce/Sm varies between 1 and 10, with sample CG-07-2 having the highest $\mathrm{Ce} / \mathrm{Sm}$ values.

The U/Ce-versus-Th diagram (fig. 6C) shows little variation in Th content in the samples derived from crustal melts, whereas the U/Ce ratio increases by two orders of magnitude. In the mantlederived samples, the $\mathrm{U} / \mathrm{Ce}$ ratio is almost constant, and Th concentration shows a significant variation.

\section{Discussion: Petrogenetic Processes and Different Melt Characteristics}

The trends observed in zircon grains analyzed from each sample and the two compositional groups defined by the analyzed samples (figs. 4, 6) could be attributed to petrogenetic processes and to differences in melt compositions. The positive correlation between the U-Th concentrations in zircon and the whole-rock $\mathrm{SiO}_{2}$ content shown in most of the samples (fig. $4 A$; table A1) proved to be characteristic of zircon grown in a melt undergoing fractional crystallization (Miller and Wooden 2004; Claiborne et al. 2006). Zircon in sample CG-07-2 is unusual because of its anomalously high uranium concentration, which is inconsistent with its low $\mathrm{SiO}_{2}$ content. Furthermore, the presence of zircon in this sample is unusual owing to its low zirconium content. This suggests that the composition of the diorite melt could not have been in equilibrium with zircon. One explanation is that zircon had grown in a late magmatic stage, far from the liquidus (Watson 1996; Hoskin and Ireland 2000; Hanchar and van Westrenen 2007). Another interpretation is that zircon is actually xenocrystic in this rock and was incorporated into the diorite melt in an early magma-mixing event. The latter interpretation is in agreement with the neodymium isotopic composition of the rock despite the absence of petrographic evidence of magma mixing.
In figure $4 B$, zircon from rocks with crustal affinity (samples CG-07-1, A-08-1, A-08-2, and A-085) defines a trend in which hafnium content increases as $T h / U$ ratio decreases. This trend is characteristic of zircon crystallizing in a magmatic system where fractional crystallization takes place (Barth and Wooden 2010; Claiborne et al. 2010b). By contrast, zircon from the mantle-derived rocks defines a different path, from high to low $\mathrm{Th} / \mathrm{U}$ and hafnium contents, which may be ascribed to the entrainment of zircon in a less fractionated melt (Claiborne et al. 2006). This contrasting trend is consistent with a mantle source involved in the evolution of these rocks during zircon growth despite the fact that all petrographic evidence of magma mixing was obliterated by metamorphic recrystallization.

The variability of hafnium concentration against $\mathrm{Eu}$ anomaly between zircon from the same sample can be regarded as a reliable fractionation index (du Bray et al. 2011). The systematic variation and the negative correlation observed in figure $6 \mathrm{~A}$ suggest that hafnium concentration increases while plagioclase fractionation occurs in the magma, indicating that the zircon composition corresponds to a real variation in the melt composition. The low Eu anomaly in both augen gneisses (samples CG-07-1 and A-08-5) suggests that zircon crystallized from highly evolved melts, where most of the plagioclase was already fractionated. This is in line with the crustal origin for these rocks. The subhorizontal trend in sample CG-07-2 suggests that the Eu anomaly was probably more controlled by the oxidizing conditions than by plagioclase fractionation (see fig. 7 in Barth and Wooden 2010).

In figure $6 B$, the $\mathrm{Ce} / \mathrm{Sm}$ ratio is used as a proxy of the oxidizing conditions in the melts during zircon growth because the oxidizing environment favors $\mathrm{Ce}^{+4}$ over $\mathrm{Ce}^{+3}$, with the result that zircon has higher $\mathrm{Ce} / \mathrm{Sm}$ ratios. In this graph, magma evolution by fractional crystallization is evaluated by means of the $\mathrm{Yb} / \mathrm{Gd}$ ratio. Claiborne et al. (2006) and Barth and Wooden (2010) observed an increase in steepness of the heavy REE pattern (measured as the $\mathrm{Yb} / \mathrm{Gd}$ ratio) as temperature decreased, and they attributed this to fractionation of middle REEs from the melt during the crystallization of accessory minerals (mainly apatite and titanite). The contrasting trends observed between the crustalderived and the mantle-derived samples could be used to determine the oxidizing characteristics of the magma. In the case of sample CG-07-2, the high $\mathrm{Ce} / \mathrm{Sm}$ values are in agreement with the variation observed in its Eu anomaly (fig. 6A), indicating high oxidizing conditions. 
The discrimination shown in the U/Ce-versusTh graph (fig. 6C) is due to the progressive increase in water content in the rocks as a result of dehydration reactions occurring during prograde metamorphism or anatexis. Under these high oxidizing conditions, the uranium valence state changes from $\mathrm{U}^{+4}$ to the more soluble $\mathrm{U}^{+6}$. Water leaves the rock as temperature increases, and the new redox conditions stabilize $\mathrm{U}^{+4}$ again. This $\mathrm{U}^{+4}$ is incorporated into zircon, which becomes more enriched in this element than in cerium. Therefore, zircon from rocks in which water plays a major role during or before its growth follows a characteristic trend (fig. $6 \mathrm{C})$ that is consistent with the crustal origin for samples A-08-1, A-08-2, A-08-5, and CG-07-1 and with the anatectic character of the last two samples.

\section{Concluding Remarks}

The study of zircon chemistry in individual samples shows that it is possible to recognize magmatic petrogenetic processes such as fractional crystallization, magma mixing, and fractionation of determined mineral species, as well as to characterize different melt compositions.

Two main groups may be defined in accordance with the differences in the composition of the samples (figs. 4, 6). These two sets coincide with the rock groups previously established for the metaigneous basement rocks in the eastern Pyrenees (Navidad et al. 2010; Liesa et al. 2011). It should be noted that these groups are characterized in line with the whole-rock geochemistry and neodymium isotopes regardless of age. One group is composed of felsic rocks with a crustal origin (samples CG07-1, A-08-1, A-08-2, and A-08-5), whereas the other group consists of felsic and mafic rocks with mantle and crustal sources (samples CG-07-2, CG07-3, and CG-07-5).

In the first group, zircons of sample CG-07-1 ( 450 Ma; Casas et al. 2010) and samples A-08-1, A-08-2, and A-08-5 ( 470 Ma; Liesa et al. 2011) exhibit similar characteristics despite the differences in age. Zircon has low Th, Th/U, Ce/Sm, and $\mathrm{Eu} / \mathrm{Eu}^{*}$ and high $\mathrm{Yb} / \mathrm{Gd}$ and $\mathrm{U} / \mathrm{Ce}$, suggesting that this mineral grew in a melt formed by anatexis of a continental crust with stable plagioclase. In the second group, the analyzed elements and ratios trace linear trends in most of the plots. They have high Th, Th/U, and Ce/Sm and low Yb/Gd and U/ $\mathrm{Ce} . \mathrm{Eu} / \mathrm{Eu}^{*}$ is variable and indicates higher oxidizing conditions in sample CG-07-2. The anomalous trend defined in the Th/U-versus-Hf plot suggests different magma pulses in the origin of these rocks.
Given their isotope geochemistry, it may be assumed that the mantle was involved in the origin of these rocks. The correlation between the europium anomaly and the hafnium content also suggests the involvement of fractional crystallization during the evolution of these rocks. However, despite the similar age ( 450 Ma; Casas et al. 2010) of the most primitive sample (CG-07-2) and samples CG-07-3 and CG-07-5, it is not possible to postulate a direct genetic relationship between themthat is, zircon geochemistry does not show that the more evolved Casemí gneisses are derived from the Marialles amphibolite. This proposition is also precluded by the anomalous composition of zircon in sample CG-07-5, which suggests a process of magma mixing to explain its presence in sample CG-07-2.

In light of our findings and given the geochemistry of the protoliths, two different Ordovician magmatic episodes can be identified in the Pyrenees to date. An Early Ordovician magmatism ( 470 Ma) gave rise to the protoliths of large gneissic bodies, such as Aston-Hospitalet, Canigó, Roc de Frausa, and Albera (Castiñeiras et al. 2008; Denele et al. 2009; Liesa et al. 2011). Melting of a recycled Neoproterozoic-Early Paleozoic crust with a Paleoproterozoic signature and calc-alkaline affinity constitutes the most probable source of crustal melts, which also gave rise to the protoliths of the Sureda gneiss and the metaporphyries. Melting is not associated with any contractional deformational or metamorphic episode, but it seems to be coeval with the development of extensional tectonics (Casas 2010). This extension is related to the breakup of the northern Gondwana margin, a wellexpressed episode in all the European Variscides (e.g., Pin and Marini 1993; von Raumer 1998; Helbing and Tiepolo 2005).

A Late Ordovician magmatic event gave rise to calc-alkaline ignimbrites, andesites, volcaniclastic rocks, diorites, and various types of granitic bodies, such as the protoliths of the Cadí and Casemí gneisses and the Marialles amphibolite (Navidad et al. 2010 and references therein). This episode was coeval with normal fault development, which enabled the input of mantle-derived melts that crystallized with varying degrees of crustal contamination.

The information extracted from zircon compositional features is in agreement with previous data obtained by whole-rock geochemistry and $\mathrm{Nd}$ isotopes (Navidad et al. 2010). This information shows how zircon composition not only reproduces the petrogenetic evolution of the host rock but also mimics the characteristics of the melt composi- 
tion, lending support to the data obtained by wholerock geochemistry and $\mathrm{Nd}$ isotopes in a set of cogenetic rocks.

\section{A C K N O W LE D G M E N T S}

This work was supported by the Spanish Commission for Science and Technology (project CGL201021298) and the Consolider-Ingenio 2010 program (under the project CSD2006-00041 "Topoiberia"). We thank the Stanford-USGS Micro-Analytical Center (SUMAC) staff at Stanford University, especially J. Wooden and F. Mazdab, for their help in operating the SHRIMP instrument and in interpreting the results. The stay of P. Castiñeiras at the SUMAC facility was funded by a Profesores UCM en el extranjero travel grant. G. von Knorring improved the English language.

\section{R E F E R E N C E S C I T E D}

Anders, E., and Grevesse, N. 1989. Abundances of the elements: meteoritic and solar. Geochim. Cosmochim. Acta, 53:197-214.

Autran, A.; Fonteilles, M.; and Guitard, G. 1970. Relations entre les intrusions de granitoides, l'anatexie, et le métamorphisme régional considerées principalment du point de vue de l'eau: cas de la chaine hercynienne des Pyrénées Orientales. Bull. Soc. Géol. Fr. 7:673-731.

Barbey, P.; Allé, P.; Brouand, M.; and Albarède, F. 1995. Rare-earth patterns in zircons from the Manaslu granite and Tibetan slab migmatites (Himalaya): insights in the origin and evolution of a crustally derived granite magma. Chem. Geol. 125:1-17.

Barth, A. P., and Wooden, J. L. 2010. Coupled elemental and isotopic analyses of polygenetic zircons from granitic rocks by ion microprobe, with implications for melt evolution and the sources of granitic magmas. Chem. Geol. 277:149-159.

Belousova, E. A.; Griffin, W. L.; O'Reilly, S. Y.; and Fisher, N. I. 2002. Igneous zircon: trace element composition as an indicator of source rock type. Contrib. Miner. Petrol. 143:602-622.

Belousova, E. A.; Griffin, W. L.; and Pearson, N. J. 1998. Trace element composition and cathodoluminescence properties of southern African kimberlitic zircons. Mineral. Mag. 62:355-366.

Black, L. P.; Kamo, S. L.; Allen, C. M.; Davis, D. W.; Aleinikoff, J. N.; Valley, J. W.; Mundil, R.; et al. 2004. Improved ${ }^{206} \mathrm{~Pb} /{ }^{238} \mathrm{U}$ microprobe geochronology by the monitoring of a trace-element-related matrix effect, SHRIMP, ID-TIMS, ELA-ICP-MS and oxygen isotope documentation for a series of zircon standards. Chem. Geol. 205:115-140.

Casas, J. M. 2010. Ordovician deformations in the Pyrenees: new insights into the significance of preVariscan ("sardic") tectonics. Geol. Mag. 147:674-689.

Casas, J. M.; Castiñeiras, P.; Navidad, M.; Liesa, M.; and Carreras, J. 2010. New insights into the Late Ordovician magmatism in the eastern Pyrenees: U-Pb SHRIMP zircon data from the Canigó massif. Gondwana Res. 17:317-324.

Castiñeiras, P.; Díaz García, F.; and Gómez Barreiro, J. 2010. REE-assisted U-Pb zircon age (SHRIMP) of an anatectic granodiorite: constraints on the evolution of the A Silva granodiorite, Iberian allochthonous complexes. Lithos 116:153-166.

Castiñeiras, P.; Navidad, M.; Liesa, M.; Carreras, J.; and Casas, J. M. 2008. U-Pb zircon ages (SHRIMP) for Cadomian and Early Ordovician magmatism in the eastern Pyrenees: new insights into the pre-Variscan evolution of the northern Gondwana margin. Tectonophysics 461:228-239.

Cavet, P. 1959. Le Paléozoïque de la zone axiale des Pyrénées orientales françaises entre le Roussillon et 1'Andorre. Bull. Serv. Carte Géol. Fr. 254:1-216.

Chen, R. X.; Zheng, Y. F.; and Xie, L. 2010. Metamorphic growth and recrystallization of zircon: distinction by simultaneous in-situ analyses of trace elements, U$\mathrm{Th}-\mathrm{Pb}$ and Lu-Hf isotopes in zircons from eclogitefacies rocks in the Sulu orogen. Lithos 114:132-154.

Claiborne, L. L.; Miller, C. F.; Flanagan, D. M.; Clyne, M. A.; and Wooden, J. L. 2010a. Zircon reveals protracted magma storage and recycling beneath Mount St. Helens. Geology 38:1011-1014.

Claiborne, L. L.; Miller, C. F.; Walker, B. A.; Wooden, J. L.; Mazdab, F. K.; and Bea, F. 2006. Tracking magmatic processes through $\mathrm{Zr} / \mathrm{Hf}$ ratios in rocks and $\mathrm{Hf}$ and $\mathrm{Ti}$ zoning in zircons: an example from the Spirit Mountain batholith, Nevada. Mineral. Mag. 70:517-543.

Claiborne, L. L.; Miller, C. F.; and Wooden, J. L. $2010 b$. Trace element composition of igneous zircon: a thermal and compositional record of the accumulation and evolution of a large silicic batholith, Spirit Mountain, Nevada. Contrib. Mineral. Petrol. 160:511-531.

Cocherie, A.; Baudin, Th.; Autran, A.; Guerra, C.; Fanning, C. M.; and Laumonier, B. 2005. U-Pb zircon (IDTIMS and SHRIMP) evidence for the early Ordovician intrusion of metagranites in the late Proterozoic Canaveilles Group of the Pyrenees and the Montagne Noire (France). Bull. Soc. Géol. Fr. 176:269-282.

Coleman, D. S.; Gray, W.; and Glazner, A. F. 2004. Rethinking the emplacement and evolution of zoned plutons: geochronologic evidence for incremental assembly of the Tuolumne Intrusive Suite, California. Geology 32:433-436.

Compston, W. 2000. Interpretation of SHRIMP and isotope dilution zircon ages for the Palaeozoic time-scale. II. Silurian to Devonian. Mineral. Mag. 64:1127-1146.

Denele, Y.; Barbey, P.; Deloule, E.; Pelleter, E.; Olivier, Ph.; and Gleizes, G. 2009. Middle Ordovician U-Pb 
age of the Aston and Hospitalet orthogneissic laccoliths: their role in the Variscan evolution of the Pyrenees. Bull. Soc. Géol. Fr. 180:209-221.

du Bray, E. A.; Bacon, C. R.; John, D. A.; Wooden, J. L.; and Mazdab, F. K. 2011. Episodic intrusion, internal differentiation, and hydrothermal alteration of the Miocene Tatoosh intrusive suite south of Mount Rainier, Washington. Geol. Soc. Am. Bull. 123:534-561.

Fontboté, J. M. 1949. Nuevos datos geológicos sobre la cuenca alta del Ter. An. Inst. Estud. Gerund. 4:57.

Gagnevin, D.; Daly, J. S.; and Kronz, A. 2010. Zircon texture and chemical composition as a guide to magmatic processes and mixing in a granitic environment and coeval volcanic system. Contrib. Mineral. Petrol. 159:579-596.

Grimes, C. B.; John, B. E.; Kelemen, P. B.; Mazdab, F. K.; Wooden, J. L.; Cheadel, M. J.; Hanghøj, K.; and Schwartz, J. J. 2007. Trace element chemistry of zircons from oceanic crust: a method for distinguishing detrital zircon provenance. Geology 35:643-646.

Guitard, G. 1970. Le métamorphisme hercynien mésozonal et les gneiss oeillés du massif du Canigou (Pyrénées-Orientales). Mém. Bur. Rech. Géol. Minières 63: 1-303.

Guitard, G.; Laumonier, B.; Autran, A.; Bandet, Y.; and Berger, G. M. 1998. Notice explicative, Carte géologique France (1:50.000), feuille Prades (1095). Orléans, Bureau Recherches Géologiques et Minières.

Hanchar, J. M., and van Westrenen, W. 2007. Rare earth element behavior in zircon-melt systems. Elements 3: 37-42.

Hanchar, J. M., and Watson, E. B. 2003. Zircon saturation thermometry. In Hanchar, J. M., and Hoskin, P. W. O., eds. Zircon. Rev. Mineral. Geochem. 53:89-112.

Heaman, L. M.; Bowins, R.; and Crocket, J. 1990. The chemical composition of igneous zircon suites: implications for geochemical tracer studies. Geochim. Cosmochim. Acta 54:1597-1607.

Helbing, H., and Tiepolo, M. 2005. Age determination of Ordovician magmatism in NE Sardinia and its bearing on Variscan basement evolution. J. Geol. Soc. Lond. 162:689-700.

Hinton, R. W., and Upton, B. G. J. 1991. The chemistry of zircon: variations within and between large crystals from syenite and alkali basalt xenoliths. Geochim. Cosmochim. Acta 55:3287-3302.

Hokada, T., and Harley, S. L. 2004. Zircon growth in UHT leucosome: constraints from zircon-garnet rare earth elements (REE) relations in Napier Complex, East Antarctica. J. Mineral. Petrol. Sci. 99:180-190.

Hoskin, P. W. O. 1998. Minor and trace element analysis of natural zircon $\left(\mathrm{ZrSiO}_{4}\right)$ by SIMS and laser ablation ICPMS: a consideration and comparison of two broadly competitive techniques. J. Trace Microprobe Tech. 16:301-326.

Hoskin, P. W. O., and Black, L. P. 2000. Metamorphic zircon formation by solid-state recrystallization of protolith igneous rocks. J. Metamorph. Geol. 18:423439.

Hoskin, P. W. O., and Ireland, T. R. 2000. Rare earth element chemistry of zircon and its use as a provenance indicator. Geology 28:627-630.

Hoskin, P. W. O., and Schaltegger, U. 2003. The composition of zircon and igneous and metamorphic petrogenesis. In Hanchar, J. M., and Hoskin, P. W. O., eds. Zircon. Rev. Mineral. Geochem. 53:27-62.

Ireland, T. R., and Wlotzka, F. 1992. The oldest zircons in the solar system. Earth Planet. Sci. Lett. 109:1-10.

Kelly, N. M., and Harley, S. L. 2005. An integrated microtextural and chemical approach to zircon geochronology: refining the Archaean history of the Napier Complex, east Antarctica. Contrib. Mineral. Petrol. 149:57-84.

Kelly, N. M.; Hinton, R. W.; Harley, S. L.; and Appleby, S. K. 2008. New SIMS U-Pb zircon ages from the Langavat Belt, South Harris, NW Scotland: implications for the Lewisian terrane model. J. Geol. Soc. Lond. 165:967-981.

Korotev, R. L. 1996. A self-consistent compilation of elemental concentration data for 93 geochemical reference samples. Geostand. Newsl. 20:217-245.

Laumonier, B. 1988. Les groupes de Canaveilles et de Jujols (“Paléozoïque inférieur») des Pyrénées orientales: arguments en faveur de l'âge essentiellement cambrien de ces séries. Hercynica 4:25-38.

Liesa, M.; Carreras, J.; Castiñeiras, P.; Casas, J. M.; Navidad, M.; and Vilà, M. 2011. U-Pb zircon age of Ordovician magmatism in the Albera massif (eastern Pyrenees). Geol. Acta 9:93-101.

Ludwig, K. R. 2003. ISOPLOT/Ex, version 3: a geochronological toolkit for Microsoft Excel. Berkeley, Berkeley Geochronol. Cent. Spec. Publ.

McClelland, W. C.; Power, S. E.; Gilotti, J. A.; Mazdab, F. K.; and Wopenka, B. 2006. U-Pb SHRIMP geochronology and trace-element geochemistry of coesitebearing zircons, North-East Greenland Caledonides. In Hacker, B. R.; McClelland, W. C.; and Liou, J. G., eds. Ultrahigh-pressure metamorphism: deep continental subduction. Geol. Soc. Am. Spec. Pap. 403:2343.

Miller, J. S.; Matzel, J. E. P.; Miller, C. F.; Burgess, S. D.; and Miller, R. B. 2007. Zircon growth and recycling during the assembly of large, composite arc plutons. J. Volcanol. Geotherm. Res. 167:282-299.

Miller, J. S., and Wooden, J. L. 2004. Residence, resorption and recycling of zircons in Devils Kitchen rhyolite, Coso volcanic field, California. J. Petrol. 45:21552170 .

Murali, A. V.; Parthasarathy, P.; Mahadevan, T. M.; and Sankar Das, M. 1983. Trace element characteristics, REE patterns and partition coefficients of zircons from different geological environments: a case study on Indian zircons. Geochim. Cosmochim. Acta 47:20472052.

Navidad, M.; Castiñeiras, P.; Casas, J. M.; Liesa, M.; Fernández Suárez, J.; Barnolas, A.; Carreras, J.; and GilPeña, I. 2010. Geochemical characterization and isotopic age of Caradocian magmatism in the northeastern Iberian Peninsula: insights into the Late 
Ordovician evolution of the northern Gondwana margin. Gondwana Res. 17:325-337.

Perejón, A.; Moreno Eiris, E.; and Abad, A. 1994. Montículos de arqueociatos y calcimicrobios del Cámbrico Inferior de Terraldes, Gerona (Pirineo Oriental, España). Bol. R. Soc. Esp. Hist. Nat. Secc. Geol. 89:5595.

Pérez Soba, C.; Villaseca, C.; González del Tánago, J.; and Nasdala, L. 2007. The composition of zircon in the peraluminous Hercynian granites of the Spanish Central System batholith. Can. Mineral. 45:509-527.

Pin, C., and Marini, F. 1993. Early Ordovician continental break-up in Variscan Europe: Nd-Sr isotope and trace element evidence from bimodal igneous associations of the Southern Massif Central, France. Lithos 29:177196.

Puga, E.; Fanning, C. M.; Nieto, J. M.; and Díaz de Federico, A. 2005. Recrystallization textures in zircon generated by ocean-floor and eclogite-facies metamorphism: a cathodoluminescence and U-Pb SHRIMP study, with constraints from REE elements. Can. Mineral. 43:183-202.

Romer, R. L., and Soler, A. 1995. U-Pb age and lead isotopic characterization of Au-bearing skarn related to the Andorra granite. Mineral. Depos. 30:374-383.

Rubatto, D. 2002. Zircon trace element geochemistry: partitioning with garnet and the link between $\mathrm{U}-\mathrm{Pb}$ ages and metamorphism. Chem. Geol. 184:123-138.

Taylor, S. R., and McLennan, S. M. 1985. The continental crust: its composition and evolution. Oxford, Blackwell Scientific.
Vilà, M. 2003. Petrogènesi i estructura hercinianes del massís de l'Albera (Pirineus orientals). PhD dissertation, Universitat de Barcelona, Spain.

von Raumer, J. F. 1998. The Paleozoic evolution in the Alps: from Gondwana to Pangea. Geol. Rundsch. 87: 407-435.

Watson, E. B. 1996. Surface enrichment and traceelement uptake during crystal growth. Geochim. Cosmochim. Acta 60:5013-5020.

Watson, E. B., and Harrison, T. M. 2005. Zircon thermometer reveals minimum melting conditions on earliest Earth. Science 308:841-844.

Whitehouse, M. J. 2003. Rare earth elements in zircon: a review of applications and case studies from the Outer Hebridean Lewisian Complex, NW Scotland. In Vance, D.; Müller, W.; and Villa, I. M., eds. Geochronology: linking the isotopic record with petrology and textures. Geol. Soc. Spec. Publ. 220:49-64.

Whitehouse, M. J., and Kamber, B. S. 2005. Assigning dates to thin gneissic veins in high-grade metamorphic terranes: a cautionary tale from Akilia, southwest Greenland. J. Petrol. 46:291-318.

Whitehouse, M. J., and Platt, J. P. 2003. Dating high-grade metamorphism-constraints from rare-earth elements in zircon and garnet. Contrib. Mineral. Petrol. 145:61-74.

Wooden, J. L.; Mazdab, F. K.; Barth, A. P.; Miller, C. F.; and Lowery, L. E. 2006. Temperatures (Ti) and compositional characteristics of zircon: early observations using high mass resolution on the USGS-Stanford SHRIMP-RG. Geochim. Cosmochim. Acta 70:A707. 